\title{
Perbedaan Motivasi Belajar melalui Pendekatan SAVI dengan Variasi Mengajar Stimulus Materi Dimensi Tiga
}

\author{
Lilis Harianti Hasibuan* \\ Fakultas Tarbiyah dan Keguruan UIN Imam Bonjol Padang \\ $\underline{\text { lilisharianti@uinib.ac.id }}$
}

\begin{abstract}
Based on the results of the research of the questionnaire score of students learning motivation mathematics then obtained an average of 76 with standard deviation 4.50 in the experimental class applied SAVI approach and average 65 with standard deviation 4.38 on the control class applied Variation Teaching Stimulus. Normality test in experimental class $\mathrm{L}_{0}=0,1296$ and $\mathrm{L}_{\text {tabel }}=0,1730$ then $\mathrm{L}_{0}<\mathrm{L}_{\text {tabel }}(0,1296<0,1730)$ and at control class $\mathrm{L}_{0}=0,1220$ and $\mathrm{L}_{\text {tabel }}=0,1730$ then $\mathrm{L}_{0}<\mathrm{L}_{\text {tabel }}(0,1220<0.1730)$ so it can be concluded that student questionnaires of both classes are normally distributed. And homogeneity test results obtained $\mathrm{F}_{\text {hitung }}<\mathrm{F}_{\text {tabel }}$ that is $(1.073<1.87)$. Seen from hypothesis test, the data of questionnaire motivation to learn mathematics $t_{\text {hitung }}>t_{\text {tabel }}(9,13>1,674)$ which $\mathrm{H}_{1}$ accepted which mean there is difference of motivation learn mathematics between SAVI approach with Variation Teaching Stimulus in cube in class VIII student of SMP Negeri 1 Padang year lessons 2015-2016. The results of observations in the experimental class applied SAVI approach obtained an average of 31.81 with a percentage of $79.52 \%$ in both categorize and in the experimental class applied Variations Teaching Stimulus obtained an average of 27.4 with percentage $68,5 \%$ is adequately.
\end{abstract}

Keywords: motivation; SAVI approach; stimulus teaching variation; study; three dimension

\begin{abstract}
Abstrak
Berdasarkan hasil penelitian dari skor angket motivasi belajar matematika siswa maka diperoleh rata-rata 76 dengan simpangan baku 4,50 pada kelas eksperimen yang diterapkan pendekatan SAVI dan rata - rata 65 dengan simpangan baku 4,38 pada kelas kontrol yang diterasi Mengajar Stimulus. Uji normalitas pada kelas eksperimen $\mathrm{L}_{0}=$ 0,1296 dan $\mathrm{L}_{\text {tabel }}=0,1730$ maka $\mathrm{L}_{0}<\mathrm{L}_{\text {tabel }}(0,1296<0,1730)$ dan pada kelas kontrol $\mathrm{L}_{0}$ $=0,1220$ dan $\mathrm{L}_{\text {tabel }}=0,1730$ maka $\mathrm{L}_{0}<\mathrm{L}_{\text {tabel }}(0,1220<0,1730)$ sehingga dapat disimpulkan bahwa angket siswa kedua kelas berdistribusi normal. Dan uji homogenitasnya diperoleh hasil $\mathrm{F}_{\text {hitung }}<\mathrm{F}_{\text {tabel }}$ yaitu $(1,073<1,87)$. Dilihat dari uji hipotesis data skor angket motivasi belajar matematika $t_{\text {hitung }}>t_{\text {tabel }}(9,13>1,674)$ yang mana $\mathrm{H}_{1}$ diterima yang berarti terdapat perbedaan motivasi belajar matematika antara pendekatan SAVI dengan Variasi Mengajar Stimulus pada kubus di kelas VIII siswa SMP Negeri 1 Padang tahun pelajaran 2015- 2016. Hasil observasi pada kelas eksperimen yang diterapkan pendekatan SAVI diperoleh rata- rata 31,81 dengan persentase 79,52\% di kategorikan baik dan pada kelas eksperimen yang diterapkan Variasi Mengajar Stimulus diperoleh rata-rata 27,4 dengan persentase 68,5\% diketagorikan cukup.
\end{abstract}

Kata Kunci : motivasi; pendekatan SAVI; variasi mengajar stimulus; belajar; dimensi tiga

*Correspondence:

Email: lilisharianti@uinib.ac.id 


\section{PENDAHULUAN}

Perkembangan ilmu pengetahuan dan teknologi yang mengalami kemajuan sangat pesat memungkinkan semua orang dapat memperoleh informasi dengan cepat dan mudah. Pendidikan adalah investasi sumber daya manusia jangka panjang yang mempunyai nilai strategis bagi kelangsungan peradaban manusia di dunia. Matematika merupakan salah satu mata pelajaran yang tergolong sangat penting dan perlu dipelajari. Sebagaimana halnya matematika merupakan salah satu penunjang dalam teknologi dan sains. Semakin maju teknologi dan sains, maka semakin banyak menuntut penggunaan matematika untuk menemukan bentuk-bentuk baru dalam disiplin ilmunya. Mata pelajaran matematika diberikan kepada siswa untuk membekali kemampuan berpikir logis, analitis, sistimatis, kritis, kreatif,serta kemamapuan bekerja sama. Matematika memiliki struktur dan kaitan yang kuat dan jelas antar konsepnya sehingga memungkinkan kita terampil berpikir rasional.

Kebanyakan siswa mengatakan bahwa pelajaran matematika merupakan pelajaran yang sulit, tidak menarik, membosankan dan lain sebagainya. Disaat siswa memiliki pemikiran bahwa matematika merupakan pelajaran yang sulit dan membosankan pada saat itu juga minat untuk belajar menurun. Dalam hal ini peran guru sangat penting, dimana guru dapat memberikan motivasi kepada siswa. Guru adalah seorang pendidik, pembimbing, pelatih dan pengembang kurikulum yang dapat menciptakan kondisi suasana belajar yang kondusif, yaitu suasana belajar menyenangkan, menarik, memberi rasa aman, memberikan ruang pada siswa untuk berpikir aktif, kreatif, dan inovatif dalam mengeksplorasi dan mengelaborasi kemampuannya. Dengan demikian, sudah suatu kewajiban bagi guru untuk mengubah pemikiran siswa mengenai matematika suatu pelajaran yang sulit dan membosankan. Apabila dalam pembelajaran guru masih menggunakan paradigma pembelajaran satu arah, yaitu umumnya dari guru ke peserta didik (Supardi, 2013). Maka guru akan lebih mendominasi pembelajaran. Dengan demikian, pembelajaran cenderung monoton sehingga mengakibatkan peserta didik merasa jenuh dan tersiksa. Oleh karena itu, dalam pembelajaran hendaknya guru memilih berbagai variasi pendekatan, strategi, metode yang sesuai dengan situasi sehingga tujuan pembelajaran yang direncanakan akan tercapai. Perlu diketahui bahwa baik atau tidaknya suatu pemilihan model pembelajaran akan tergantung tujuan pembelajarannya, kesesuaian dengan materi pembelajaran, tingkat perkembangan peserta didik, kemampuan guru dalam mengelola pembelajaran serta mengoptimalkan sumber-sumber belajar yang ada (Hidayat, W., Wahyudin, \& Prabawanto, 2018).

Dalam upaya meningkatkan motivasi belajar matematika siswa dengan menggunakan pendekatan SAVI, materi kubus merupakan materi yang tepat karena secara langsung siswa dapat menggunakan alat peraga dan membuatnya 
sendiri dengan kata lain dalam hal ini siswa sudah ikut serta berperan aktif dalam proses pembelajaran, dengan mempraktekkan secara langsung apa yang dipelajari akan menumbuhkan minat untuk belajar matematika. Siswa akan merasa senang apabila bisa secara langsung bisa mempraktekkan apa yang dipelajarinya dan akan termotivasi dalam pembelajaran.

Berdasarkan hasil observasi awal peneliti di SMP Negeri 1 Padang ditemukan kesenjangan-kesenjangan sikap siswa khususnya kelas VIII-D dan VIII-E dalam mempelajari matematika diantaranya dalam proses pembelajaran masih terdapat beberapa permasalahan, antara lain: kurangnya keinginan siswa untuk belajar matematika, kurangnya respon siswa terhadap pembelajaran matematika, siswa kurang memperhatikan penjelasan guru pada saat pembelajaran, siswa tidak mempunyai kemauan dan motivasi dalam pembelajaran matematika, konsentrasi siswa kurang terfokus pada pembelajaran matematika, lingkungan belajar yang kurang kondusif, dan kurangnya keaktifan siswa dalam pembelajaran matematika. Rendahnya motivasi belajar matematika siswa terlihat dari kurangnya keinginan siswa untuk belajar matematika, kurangnya respon siswa terhadap pembelajaran matematika, kurangnya minat atau keinginan siswa untuk memahami materi dalam belajar matematika, tidak adanya perhatian dan partisipasi siswa saat guru memberikan materi pelajaran, sehingga hasil belajar yang diperoleh siswa sangat rendah. Kondisi seperti ini dapat terjadi karena tidak ada dorongan dari guru, sesuatu yang menggerakkan dan mengarahkan siswanya untuk lebih giat belajar, lingkungan belajar yang tidak kondusif sehingga siswa tidak dapat belajar dengan baik, tidak adanya kegiatan menarik dalam belajar dan pendekatan yang diterapakan guru masih kurang tepat, seperti dalam penyampaian materi hanya berpatokan pada satu buku, guru cenderung memberi tugas kepada siswa, tanpa ada tindak lanjut untuk dibahas dan diselesaikan bersama-sama, serta dalam kondisi belajar guru tidak memperhatikan perkembangan siswa.

Salah satu pendekatan yang dianggap tepat digunakan untuk memotivasi siswa dalam belajar pada materi tiga dimensi adalah pendekatan SAVI. Dimana dalam penelitian (Ulvah \& Afriansyah, 2016) ditemukan bahwa siswa benar-benar terlibat dalam pembelajarannya, dan terlihat nyaman dengan model pembelajaran yang SAVI diterapkan. Selain itu dalam (Wulansari, Ratna, Roesdiana, Lessa, dan Imami, 2019) pencapaian kemampuan representasi matematis siswa yang mendapatkan pembelajaran model Somatic, Auditory, Visualization, Intellectualy (SAVI) lebih baik dari siswa yang mendapatkan pembelajaran biasa. Apabila sebuah pembelajaran dapat melibatkan seluruh unsur SAVI ini maka pembelajaran akan berlangsung efektif karena dalam pembelajaran perlu adanya keaktifan secara fisik sehingga membantu melatih pola pikir siswa dalam memecahkan masalah dengan kritis, logis, cepat, dan tepat.

Menurut pernyataan guru matematika yang masuk di kelas VIII SMP Negeri 1 Padang "Siswa yang benar-benar memperhatikan dan mengikuti 
pelajaran dengan baik hanya beberapa orang saja, jika dipersentasekan kira - kira $35 \%$ yang benar-benar serius, $40 \%$ terkadang serius, dan $25 \%$ yang kurang serius. Itu terlihat dari hasil ulangan yang mereka dapat saat ulangan. Selain itu dapat dilihat dari tingkah laku siswa saat kita sedang mengajar. Selalu adanya siswa yang mengganggu siswa yang lain. Sehingga pembelajaran jadi tidak terkendali, dan pada saat itu terkadang emosi tidak dapat tertahankan, yang akhirnya menghukum siswa yang menyebabkan keributan tersebut".

Berdasarkan pernyataan guru matematika yang masuk ke kelas VIII SMP Negeri 1 Padang. Pernyataan persentase keaktifan siswa 35\% yang benar-benar serius, 35\% dari 27 orang berarti hanya 9 orang yang benar-benar serius, $40 \%$ yang terkadang serius, $40 \%$ dari 27 orang berarti ada 11 orang yang terkadang serius, $25 \%$ siswa yang kurang serius, $25 \%$ dari 27 orang berarti 7 orang yang kurang serius. Dikatakan serius berarti yang benar-benar ingin belajar, dimana keinginan untuk belajar memang dari dalam diri siswa tersebut. Terkadang serius berarti kadang minat belajarnya tinggi dan kadang rendah, dalam hal ini masih mudah terpengaruh oleh siswa yang lain. Kurang serius berarti masih belum menyadari akan pentingnya belajar sehingga kurang serius dalam belajar. Dari persentase tersebut antara siswa yang serius belajar dan kurang serius belajar hampir memiliki persentase yang sama. Oleh sebab itu, berbagi cara dapat dilakukan dalam menanggulangi permasalahan-permasalahan yang terjadi dalam proses pembelajaran. Misalnya dengan pemberian motivasi kepada siswa, melakukan pendekatan dan menggunakan model pembelajaran yang tepat. Pendekatan SAVI bisa dijadikan salah satu alternatif untuk mengaktifkan siswa dalam belajar.

Pembelajaran SAVI (Somatic, Audiotori, Visual, Intelektual) adalah pembelajaran yang menekankan bahwa belajar haruslah memanfaatkan semua alat indera yang dimiliki siswa. Somatis artinya belajar dengan bergerak dan berbuat. Audiotori belajar dengan berbicara dan mendengarkan. Visual artinya belajar dengan memecahkan masalah dan menerangkan. Intelektual artinya memecahkan masalah dan merenung (Abbas Gilakjani P, 2012).

Pembelajaran matematika dengan pendekatan SAVI bisa optimal jika keempat unsur SAVI ada dalam satu peristiwa pembelajaran matematika. Misalnya, siswa akan belajar sedikit tentang matematika dengan menyaksikan presentasi (V), tetapi mereka dapat belajar lebih banyak jika mereka melakukan sesuatu (S), membicarakan atau mendiskusikan apa yang mereka pelajari (A), serta memikirkan dan mengambil kesimpulan atau informasi yang mereka peroleh untuk diterapkan dalam menyelesaikan soal-soal (I) (Abbas Gilakjani P, 2012). Selain itu untuk mengetahui perbedaan motivasi belajar matematika antara pendekatan SAVI dan Variasi Mengajar Stimulus akan dilaksanakan 
pembelajaran di dua kelas berbeda tapi memiliki jumlah siswa yang sama dan memiliki kemampuan rata-rata yang sama juga.

Menurut Jerome Bruner (Suherman, 2003) mengatakan bahwa belajar matematika akan lebih berhasil jika proses pengajaran diarahkan pada konsepkonsep dan struktur-struktur. Bruner, melalui teorinya itu, mengungkan bahwa dalam proses belajar anak sebaiknya diberi kesempatan untuk memanipulasi benda-benda (alat peraga). Melalui alat peraga tersebut anak akan melihat langsung bagaimana keteraturan dan pola struktur yang terdapat dalam benda yang diperhatikannya itu. Keteraturan tersebut kemudian oleh anak dihubungkan dengan keterangan intuitif yang telah melekat pada dirinya. Menurut Mc. Donald dalam kutipan (Sardiman, 2014) motivasi adalah perubahan energi dalam diri seseorang yang ditandai dengan munculnya felling dan didahului dengan tanggapan terhadap adanya tujuan.

Banyak teori motivasi yang didasarkan dari asas kebutuhan (need). Kebutuhan yang menyebabkan sesorang berusaha untuk dapat memenuhinya. Motivasi adalah proses psikologis yang dapat menjelaskan perilaku seseorang untuk mencapai tujuan dimana untuk mencapai tujuan tersebut diperlukan interaksi dari beberapa unsur. Dengan demikian, motivasi merupakan kekuatan yang mendorong seseorang melakukan sesuatu untuk mencapai tujuan. Kekuatankekuatan ini pada dasarnya dirangsang berbagai macam kebutuhan seperti: keinginan yang hendak dipenuhinya, tingkah laku, tujuan, umpan balik. Proses interaksi ini disebut sebagai produk motivasi dasar (basic motivations process), dapat digambarkan dengan model proses seperti berikut:

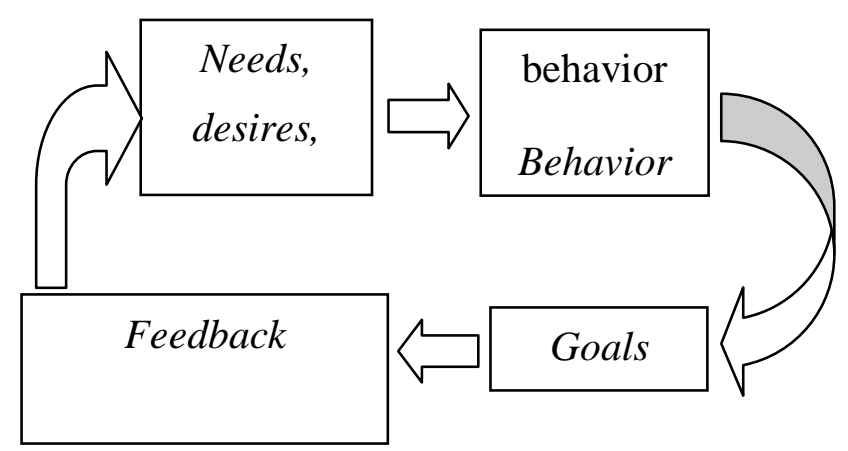

Gambar 1. Proses Motivasi Dasar

(B. Uno, 2014)

Hakikat motivasi belajar adalah dorongan internal dan eksternal pada siswa-siswa yang sedang belajar untuk mengadakan perbahan tingkah laku, pada umumnya dengan beberapa indikator atau unsur yang mendukung. Hal itu mempunyai peranan besar dalam keberhasilan seseorang dalam belajar. 


\section{Macam-macam motivasi}

Motivasi belajar dibedakan menjadi dua, yaitu :

a. Motivasi Intrinsik: yang dimaksud dengan motivasi intrinsik adalah motifmotif yang menjadi aktif atau berfungsinya tidak perlu dirangsnag dari luar, karena dari dalam diri setiap individu sudah ada dorongan untuk melakukan sesuatu (Sardiman, 2014).

b. Motivasi Ekstrinsik

(Sardiman, 2014) menyatakan bahwa motivasi ekstrinsik adalah motif-motif yang aktif dan berfungsinya karena adanya perangsang dari luar. Motivasi ekstrinsik juga dapat dikatakan sebagai bentuk motivasi yang di dalamnya aktivitas belajar dimulai dan diteruskan berdasarkan dorongan dari luar yang secara tidak mutlak berkaitan dengan aktivitas belajar.

Selanjutnya (Dimyati dan Mudjiono, 2009) menjelaskan bahwa motivasi ekstrinsik adalah dorongan terhadap perilaku seseorang yang ada di luar perbuatan yang dilakukannya. Misalnya, seseorang berbuat sesuatu karena dorongan dari luar seperti adanya hadiah dan menghindari hukuman.

\section{Pendekatan SAVI}

Pendekatan SAVI diperkenalkan pertama kali oleh Dave Meier. Kepanjangan dari SAVI adalah Somatis, Audiotori, Visual, dan Intelektual. Teori yang mendukung pembelajaran SAVI adalah Accelereated Learning, teori otak kanan atau kiri, teori otak triune, pilihan modalitas (visual, audiotorial dan kinestik), teori kecerdasan ganda, pendidikan (holistic) menyeluruh, belajar berdasarkan pengalaman, belajar dengan simbol.

Pendekatan SAVI termasuk pendekatan yang berpusat pada siswa (Students Centered Aproach). (DePorter, Bobbi dan Hernacki, 2000) mengungkapkan bahwa anak memiliki tiga gaya belajar yang berbeda sebagai modalitas awal dalam belajar yaitu visual, audiotorial, kinestik/somatik. Dave Meier menambahkan lagi modalitas dalam belajar anak, yaitu modalitas intelektuan.

\section{Variasi Mengajar Stimulus}

Keterampilan dasar mengajar merupakan syarat mutlak agar bisa mengimplementasikan berbagai strategi pembelajaran karena pembentukan performance guru yang baik diperlukan keterampilan dasar mengajar. Menurut (Asril, 2013) "Keterampilan dasar adalah keterampilan standar yang harus dimiliki setiap individuyang berprofesi sebagai guru". Untuk itu keterampilan guru harus dilatih dan dikembangkan sehingga para guru memiliki kemampuan untuk melayani siswa dalam melakukan kegiatan pembelajaran. Sepintas 
keterampilan itulah yang membedakan man guru yang profesional dan mana yang bukan guru.

Variasi stimulus dalam gaya guru yang profesional harus hidup dan antusias menarik minat belajar peserta didik. Menurut T. Gilarso (dalam Asril, 2013) menyatakan bahwa "variasi stimulus dalam gaya mengajar guru dapat dilakukan antara lain dalam bentuk: Pertama verbal (dengan menggunakan suara dan kata-kata yang diucapkan guru) seperti: (1) nada suara dan intonasi (voice variation), (2) mengarahkan perhatian peserta didik (verbal focussing), (3) mengadakan pause/diam sebentar (pausing/silence), (4) isyarat-isyarat lisan lain (extra verval). Kedua, non verbal (dengan isyarat/ bahasa badan) yang mencakup: (1) kontak pandangan mata (eye contact), (2) ekspresi roman muka (facial expressions), (3) gerak gerik tangan, kepala, badan (gestures), (4) posisi (tempat berdiri di kelas) (Asril, 2013).

1. Variasi stimulus Gaya Mengajar

Variasi stimulus gaya mengajar pada dasarnya meliputi variasi stimulus suara, penekanan, pemberian waktu, kontak pandang, gerakan anggota badan dan pindah posisi.

a. Variasi stimulus suara

Pada variasi stimulus suara guru perlu memperhatikan intonasi, nada, volume, dan kecepatan. Guru dapat mendramatiskan suatu peristiwa dengan menunjukkan hal-hal yang penting, berbicara dengan suara yang pelan atau dengan suara yang tajam terhadap anak didik yang kurang perhatian. Guru berusaha menghindari suara yang lemah yang mengakibatkan suara tidak bisa ditangkap anak didik, pengucapan kalimat harus jelas sehingga anak didik tidak salah dalam mengartikan, dan pengucapan kata yang sama dan berulang-ulang harus dihindari,

b. Variasi stimulus penekanan (focusing)

Penekanan digunakan untuk memfokuskan perhatian anak didik. Penggunaan kata yang bervariasi stimulus sangat dianjurkan, misalnya:

- Perhatikan baik-baik! Penggunaan diagram venn sedikit lebih sukar, jadi perhatikan dengan baik-baik.

- Coba anda perhatikan dengan seksama diagram venn ini!

- Dengarkan baik- baik penjelasan ibu ini!

c. Variasi stimulus waktu (pausing)

Untuk menarik perhatian anak didik yamg mulai ribut, ubah suasana menjadi sepi dengan kebisuan guru, kegiatan diberhentikan sejenak dengan memperhatikan siswa satu persatu. Trik ini akan membuat anak didik diam dan ketenangan dalam belajar. Pemberian waktu juga diberikan untuk mencari dan memikirkan jawaban pertanyaan yang diberikan sehingga semua anak didik berusaha menemukan jawaban.. 
d. Kontak pandang

Gunakan kontak pandang kesemua anak didik jangan pernah pandang bulu. Semua anak didik ingin diperhatikandan mendapat penghargaan. Kontak mata dapat menjadi magnet untuk menarik perhatian anak didik dan juga cara menyampaikan informasi.

e. Gerakan anggota badan (gesturing)

Gerakan badan juga bisa menyampaikan informasi, seperti menunjuk seseorang. Mimik wajah juga dapat menyemangati belajar anak didik.

f. Pindah posisi

Perpindahan posisi guru juga sangat membantu mengkodusifkan kegiatan belaja mengajar. Perpindahan posisi juga harus ada tujuannya. Jika guru hanya berdiri di depan saja maka anak didik yang bereda di belakang akan bebas melakukan apa saja.

2. Variasi stimulus Media dan bahan Ajaran

Pada materi himpunan variasi stimulus media juga dapat digunakan seperti penggunaan gambar, media komputer (alat bantu in fokus) dan lainnya. Penggunaan media juga harus bervariasi stimulus agar anak didik tidak merasa bosan. Namun media juga harus disesuaikan dengan indra anak didik.

3. Variasi stimulus Interaksi

Pembelajaran adalah proses interaksi antara siswa dengan lingkungannya. Guru harus membangun interaksi dengan memberikan kesempatan seluas-luasnya kepada anak didik untuk berinteraksi dengan lingkungan. Pada psoses interaksi guru harus menghindari banyak bicara atau terlalu lama. Kesalahan yang sering terjadi pada proses pembelajaran aadalah interaksi satu arah, yaitu dari guru kepada anak didik. Karena itu guru perlu menggunakan variasi stimulus interaksi dua arah atau multi arah.

Dimana pada pembelajaran konvensioanal siswa hanya berperan pasif dan guru yang aktif. Variasi Mengajar Stimulus adalah pendekatan dengan metode ceramah, tanya jawab, diskusi sebagaimana pembelajaran yang sebelumnya dilaksanakan, sebelum diketahuinya strategi, model dan motede pembelajaran seperti saat ini.Berdasarkan uraian di atas maka peneliti tertarik untuk melaksanakan penelitian dengan judul "Perbedaan Motivasi Belajar Matematika Antara Pendekatan SAVI dengan Variasi Mengajar Stimulus Pada Kubus di Kelas VIII Siswa SMP Negeri 1 Padang Tahun Pelajaran 2019/2020”

\section{METODE PENELITIAN}

Penelitian yang digunakan peneliti dalam tindakan ini adalah penelitian eksperimen. (Arikunto, 2013; Rangkuti, 2016; Sugiyono, 2012) penelitian eksperimen merupakan suatu cara untuk mencari hubungan sebab akibat (hubungan kausal) antara dua faktor yangs engaja ditimbulkan oleh peneliti 
dengan mengeliminasi atau mengurangi atau menyisihkan faktor-faktor lain yang mengganggu. Eksperimen selalu dilakukan dengan maksud untuk melihat akibat suatu perlakuan. Dalam penelitian ini penulis menggunakan dua kelas yaitu kelas eksperimen dan kelas kontrol.

Tabel 3.Rancangan Penelitian

\begin{tabular}{ccc}
\hline Kelas & Perlakuan & Instrumen \\
\hline Eksperimen & $\mathrm{X}_{1}$ & $\mathrm{~T}_{1}$ \\
\hline Kontrol & $\mathrm{X}_{2}$ & $\mathrm{~T}_{2}$ \\
\hline
\end{tabular}

Keterangan :

$\mathrm{X}_{1} \quad$ : Perlakuan yang diberikan pada kelas eksperimen, berupa pemebelajaran dengan pendekatan SAVI

$\mathrm{X}_{2}$ : Perlakuan yang diberikan pada kelas kontrol, berupa pemebelajaran dengan Variasi Mengajar Stimulus

$\mathrm{T}_{1} \quad$ : Angket motivasi belajar matematika pada kelas eksperimen

$\mathrm{T}_{2} \quad$ : Angket motivasi belajar matematika pada kelas control

\section{Populasi dan Sampel}

Populasi dalam penelitian ini adalah semua kelas VIII SMP Negeri 1 Padang Tahun Pelajaran 2019-2020 sebanyak lima kelas dengan jumlah keseluruhannya sebanyak 136 siswa.

Tabel 4. Jumlah Populasi Siswa Kelas VIII SMP Negeri 1 Angkola Barat

\begin{tabular}{ccc}
\hline No & Kelas & Jumlah \\
\hline 1 & VIII-A & 27 \\
\hline 2 & VIII-B & 27 \\
\hline 3 & VIII-C & 28 \\
\hline 4 & VIII-D & 27 \\
\hline 5 & VIII-E & 27 \\
\hline & Jumlah & 136 Orang
\end{tabular}

Sumber Tata Usaha SMP Negeri 1 Padang Tahun Ajaran 2019/2020.

Setelah dilakukan pengambilan sampel secara acak maka diperoleh kelas VIII-D yang berjumlah 27 orang sebagai kelas eksperimen yang akan diterapkan dengan pendekatan SAVI dan kelas VIII-E yang berjumlah 27 orang sebagai kelas kontrol yang akan diterapkan dengan pendekatan variasimengajar. 


\section{HASIL DAN PEMBAHASAN}

Setelah dilakukan perhitungan, didapatkan nilai rata-rata 76 dengan simpangan baku 4,54 pada kelas eksperimen yang diajar dengan pendekatan SAVI. Jika kita kualifikasikan berdasarkan kualifikasi hasil persentase skor angket maka rata-rata 76 dinyatakan kategori "tinggi". Artinya pembelajaran dengan pendekatan SAVI dapat meningkatkan motivasi belajar matematika.

Pada kelas kontrol yang diajarkan dengan pendekatan variasi mengajar diperoleh rata-rata 65 dengan simpangan baku 4,38. Jika kita kualifikasikan berdasarkan kualifikasi hasil persentase skor angket maka rata-rata 65 dinyatakan kategori "sedang". Artinya pembelajaran dengan pendekatan konvensional masih perlu adanya peningkatan dalam pembelajaran untuk mencapai hasil yang lebih baik lagi.

Tabel 5. Data Skor Angket pada Kelas Eksperimen dan Kelas Kontrol

\begin{tabular}{ccccc}
\hline No & $\begin{array}{c}\text { Nilai Kelas } \\
\text { Eksperimen }\end{array}$ & Frekuensi & $\begin{array}{c}\text { Nilai Kelas } \\
\text { Kontrol }\end{array}$ & Frekuensi \\
\hline 1 & 68 & 3 & 58 & 2 \\
\hline 2 & 70 & 1 & 60 & 4 \\
\hline 3 & 72 & 2 & 62 & 4 \\
\hline 4 & 74 & 4 & 64 & 4 \\
\hline 5 & 76 & 7 & 66 & 3 \\
\hline 6 & 78 & 3 & 68 & 3 \\
\hline 7 & 80 & 3 & 70 & 3 \\
\hline 8 & 82 & 2 & & \\
\hline 9 & 84 & 2 & 65 & \\
\hline Jumlah & & 27 & 4,38 & \\
\hline- & 76 & & & \\
\hline SD & 4,54 & & & \\
\hline$S^{2}$ & 20,61 & & & \\
\hline
\end{tabular}




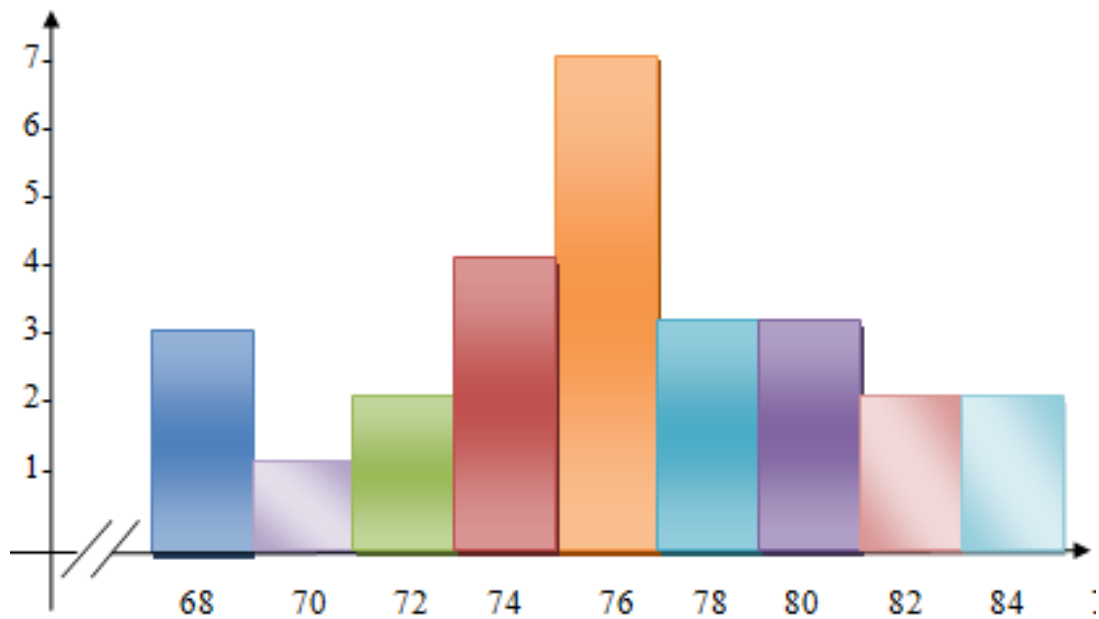

Gambar 2. Histogram data skor angket motivasi belajar matematika siswa dengan pendekatan variasi mengajar

Sedangkan untuk hasil observasi dari kelas control dan kelas eksperimen dapat dilihat pada tabel berikut ini :

Tabel 6. Rata-Rata Persentase Observasi pada Kelas Eksperimen dan Kelas Kontrol

\begin{tabular}{cccc}
\hline Kelas & Rata-rata & Persentase & Kategori \\
\hline Eksperimen & 31,81 & $79,5 \%$ & Baik \\
\hline Kontrol & 27,4 & $68,5 \%$ & Cukup \\
\hline
\end{tabular}

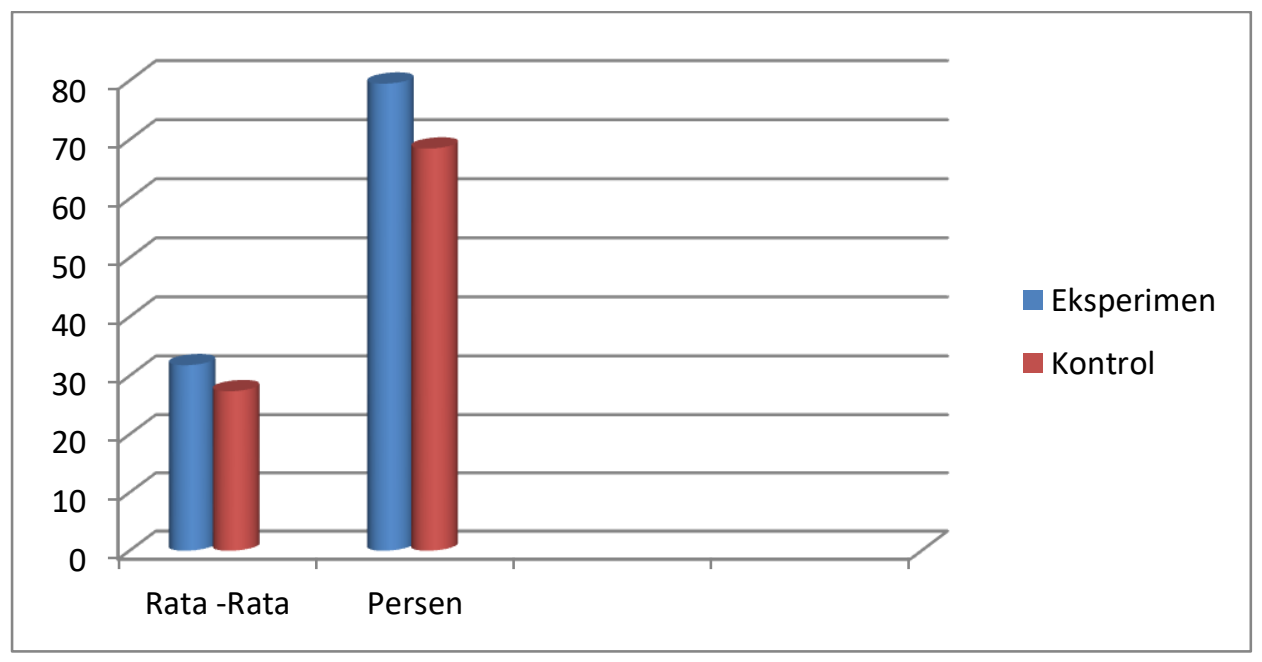

Gambar 3. Grafik Rata-Rata Persentase Observasi pada Kelas Eksperimen dan Kelas Kontrol 
Berdasarkan hasil observasi dalam penelitian ini dimana pada kelas eksperimen yang terapkan pendekatan SAVI maka diperoleh rata-rata 31,81 dengan persentase 79,52 \% di kategorikan baik, perhitungan hasil observasi di kelas eksperimen ada pada lampiran 14. Pada kelas kontrol yang diterapkan Variasi Mengajar Stimulus diperoleh rata-rata 27,4 dengan persentase 68,5\% diketagorikan cukup perhitungan hasil observasi di kelas kontrol ada pada lampiran 16. Dalam hal ini jelas bahwa penerapan pendekatan SAVI lebih baik dibandingkan dengan pembelajaran dengan Variasi Mengajar Stimulus. Dimana motivasi belajar matematika lebih tinggi berdasarkan hasil observasi yang telah dilaksanakan.

Berdasarkan deskripsi data dan setelah melalui perhitungan-perhitungan analisa data yang telah dipaparkan di atas, terlihat bahwa motivasi belajar matematika dengan penerapan pendekatan SAVI lebih tinggi jika dibandingkan dengan penerapan pendekatan konvensional. Dimana rata-rata skor angket motivasi belajar matematika siswa yang diajar dengan pendekatan SAVI lebih tinggi dibandingkan dengan skor angket motivasi belajar matematika siswa yang diajar dengan pendekatan Variasi Mengajar.

Adapun nilai rata-rata pada kelas eksperimen yang diterapkan pendekatan SAVI adalah 76 dikategorikan tinggi dengan standar deviasi 4,54 dan nilai ratarata pada kelas kontrol yang diterapkan pendekatan konvensional adalah 65 dengan standar deviasi 4,38 dikategorikan sedang.

Dengan demikian dari hasil pembahasan penelitian ini disimpulkan bahwa terdapat perbedaan motivasi belajar matematika antara pendekatan SAVI dengan pendekatan variasimengajarpada kubus di kelas VIII siswa SMP N egeri 1 Padang tahun pelajaran 2019-2020. Hal ini disebabkan antara lain:

1. Melalui pengajaran dengan penerapan pendekatan SAVI, motivasi, minat dan rasa ingin tahu siswa lebih tinggi karena secara langsung ikut serta dan berperan aktif selama proses belajar berlangsung.

2. Dengan pendekatan SAVI siswa dapat mempraktekkan apa yang dipelajarinya,misalnya dengan membuta jaring-jaring kubus dari kertas karton. Dengan mempraktekkan apa yang dipelajari tentu akan menambah daya ingat dalam pikiran siswa. Karena apabila kita mendengar, memperhatikan, mencatat, dan mempraktekkan apa yang dipelajari akan lebih bertahan jika dibandingkan dengan yang hanya mendengarkan saja.

3. Dengan berperan aktif selama proses pembelajaran dan mengalami sendiri, maka siswa akan lebih mudah mentransfer apa yang diketahuinya pada situasi proses belajar dan mengingatnya lebih lama.

4. Pengajaran dengan pendekatan SAVI dapat meningkatkan motivasi belajar matematika siswa, karena siswa ikut serta mempraktekkan apa yang dipelajari dan diajak untuk mengalami sendiri, sedangkan pengajaran dengan pendekatan 
konvensional merupakan kegiatan penyampaian materi pelajaran oleh guru, dimana kegitan inti berpusat pada guru (teacher center) dan komunikasi berlangsung satu arah.

\section{KESIMPULAN}

Dari deskripsi hasil penelitian dan pembahasan pada sebelumnya dapat diambil kesimpulan sebagai berikut: bahwa rata-rata dari skor angket motivasi belajar matematika yang diajar dengan pendekatan SAVI dikelas eksperimen adalah 76, berdasarkan kualifikasi hasil persentase skor angket maka rata-rata 76 dinyatakan kategori "tinggi". Artinya pembelajaran dengan pendekatan SAVI dapat meningkatkan motivasi belajar matematika. Sedangkan standar deviasinya adalah 4,54. Standar deviasi merupakan rata-rata penyimpangan skor sampel terhadap rata-rata sampel. Selanjutnya untuk hasil observasi diperoleh rata-rata 31,81 dengan persentase 79,52\% di kategorikan baik.

\section{DAFTAR PUSTAKA}

Abbas Gilakjani P. (2012). Visual, Auditory, Kinaesthetic Learning Styles and Their Impacts on English Language Teaching, 2(1).

Arikunto, S. (2013). Prosedur Penelitian: Suatu Pendekatan Praktek. Jakarta: PT Rineka Cipta.

Asril, Z. (2013). Micro Teaching Disertai dengan Pedoman Pengalaman Lapangan. Jakarta: Rajawali Pers.

B. Uno, H. (2014). Teori Motivasi dan Pengukurannya. Jakarta: Bumi Aksara.

DePorter, Bobbi dan Hernacki, M. (2000). Quantum Learning. Bandung: Mizan Media Utama.

Dimyati dan Mudjiono. (2009). Belajar dan Pembelajaran. Jakarta: Rineka Cipta.

Hidayat, W., Wahyudin, \& Prabawanto, S. (2018). Improving students' creative mathematical reasoning ability students through adversity quotient and argument driven inquiry learning. In Journal of Physics: Conference Series, 948(1), 012005.

Rangkuti, A. N. (2016). Metode Penelitian Pendidikan Pendekatan Kuantitafi, Kualitatif, PTK, dan Penelitian Pengembangan. Bandung: Citaputaka Media.

Sardiman, A. M. (2014). Interaksi \& Motivasi Belajar Mengajar. Jakarta: PT Raja Grafindo Persada.

Sugiyono. (2012). Metode Penelitian Pendidikan, Pendekatan Kuantitatif, 
Kualitatif, dan $R \& D$. Bandung: Alfabeta.

Suherman, E. (2003). Strategi Pembelajaran Matematika Kontemporer. Bandung: JICA UPI.

Supardi, U. . (2013). Pengaruh Adversity quotient Terhadap Prestasi Belajar Matematika. Jurnal Formatif, 3(1), 61-71.

Ulvah, S., \& Afriansyah, dan E. A. (2016). Kemampuan Pemecahan Masalah Matematis Siswa ditinjau melalui Model Pembelajaran SAVI dan Konvensional. Jurnal Riset Pendidikan, 2(2).

Wulansari, Ratna, Roesdiana, Lessa, dan Imami, A. I. (2019). Pengaruh Model Somatic Auditory Visualization Intellectualy (SAVI) terhadap Kemampuan Representasi Matematis Siswa SMP. Prosiding Sesiomadika, 1(2). 